\title{
Pemetaan dan strategi kebijakan: dampak kerusakan tanah untuk produksi biomasa di Kota Depok
}

\author{
Tatan Sukwika*, Irman Firmansyah** \\ * Program Studi Teknik Lingkungan, Fakultas Teknik, Universitas Sahid Jakarta, \\ Indonesia \\ * Sistem Dinamik Center, Indonesia
}

\section{ARTICLES INFO}

Profil Articles:

Sent: 19-2-2019

Approved: 24-6-2019

Published: 30-1-2020

Key words:

Depok municipality; soil

damage; biomass

production; policy

strategy

\section{Correspondent Author:}

Tatan Sukwika

Program Studi Teknik Lingkungan

Universitas Sahid Jakarta

J1. Prof. Dr. Supomo No. 84, Jakarta 12870

E-mail: tata.swk@gmail.com

Depok area was planned to had a harmonious use of space between settlements, socio-economic activities and conservation efforts. The rapid growth of the region had implications for land needs, including conversion of agricultural land. The area indicated with high potential for soil damage for biomass production was the Sawangan district. The purpose of study was the mapping of policy strategies for preventing soil damage for biomass production. The method used was survey mapping and descriptive analysis. The result shows that status of land damage for biomass production was categorized as moderate and high category. The priority policy was to reduce the use of chemical fertilizers and the application of liming before planting. The recommendation was that the "moderate" land damage category was for dry land-use, while the "high" category was as land-use for vacant land.

\begin{abstract}
Kawasan Depok direncanakan terdapat pemanfaatan ruang yang serasi antara untuk permukiman, kegiatan sosial ekonomi dan upaya konservasi. Pesatnya pertumbuhan kawasan berimplikasi pada kebutuhan lahan, antara lain konversi lahan pertanian. Kawasan yang diindikasi potensi kerusakan tanah tinggi untuk produksi biomassa adalah kecamatan Sawangan. Tujuan kajian penelitian ini adalah pemetaan strategi kebijakan untuk pencegahan kerusakan tanah untuk produksi biomassa. Metode yang digunakan adalah survei pemetaan dan analisis deskriptif. Hasil penelitian menunjukan bahwa status kerusakan lahan untuk produksi biomassa adalah kategori sedang dan tinggi. Berdasarkan hirarki alternatif kebijakan terdapat prioritas pengurangan penggunaan pupuk kimia dan penerapan pengapuran sebelum masa tanam. Rekomendasinya, kerusakan tanah kategori "sedang" untuk penggunaan lahan kering, sedangkan kategori "tinggi" untuk penggunaan lahan tanah kosong.
\end{abstract}

This is an open access article under the CC-BY-SA license

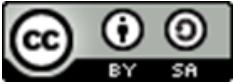


Jurnal Pendidikan Geografi:

Kajian, Teori, dan Praktik dalam Bidang Pendidikan dan Ilmu Geografi

Volume 25, Nomor 2, Jun 2020, Hal 114-127

(2015) yang diantaranya menyebutkan adanya rencana pemanfaatan ruang untuk permukiman, perbaikan pengelolaan sumberdaya alam dan lingkungan hidup, dan peningkatan kenyamanan kota. Depok memiliki wilayah seluas $200,29 \mathrm{~km}^{2}$ dan berpenduduk 2.254.513 jiwa (BPS-Depok, 2018). Kota depok telah membentuk beberapa SPK (sub-pusat pelayan kota) salah satunya SPK Sawangan. SPK sawangan ini mencakup 2 kecamatan yaitu Sawangan dan Bojongsari. Seiring dengan pesatnya pertumbuhan pembangunan kota Depok, tentunya berimplikasi kepada kebutuhan lahan, diantaranya melalui konversi lahan pertanian. Hal ini tergambarkan dalam dokumen RTRW (rencana tata ruang wilayah) kota Depok, dimana disebutkan terjadi penyusutan terhadap luas RTH (ruang terbuka hijau) sebesar 3,63\%. Sebaliknya, kawasan terbangun untuk permukiman mengalami peningkatan sebesar 3,59\%. Jika alih fungsi lahan pertanian untuk Kawasan terbangun tidak disikapi dengan baik, maka kebijakan mengkonversi lahan pertanian tersebut justru malah menjadi masalah baru lingkungan (Sukwika, 2018) seperti menurunnya kualitas lahan atau degradasi tanah (El-Gammal et al., 2015; Firmansyah dan Sukwika, 2020).

Di kota Depok, daerah yang mempunyai indikasi potensi kerusakan tanah tinggi adalah kecamatan Sawangan. Kajian Setyani et al. (2017) dan Syarmalina et al. (2017) menunjukkan adanya masalah lingkungan berupa pengurangan RTH dan pemadatan permukiman yang berimplikasi terhadap kualitas tanah. Perubahan pola pemanfaatan lahan ini berpotensi terhadap kerusakan tanah disekitarnya, khususnya untuk produksi biomassa. Kerusakan tanah bisa diakibatkan oleh penggunaan lahan di atas tanah tersebut. Kerusakan tanah pun bisa sebagai penyebab masalah pada tiap penggunaan lahan. Berdasarkan Permen LH (2008) tanah merupakan salah satu komponen lahan, didalamnya mencakup bahan mineral dan bahan organik yang mempunyai sifat fisik, kimia, biologi, dan mempunyai kemampuan menunjang kehidupan makhluk hidup. Kerusakan tanah adalah berubahnya sifat dasar tanah yang melampaui kriteria baku kerusakan tanah untuk produksi biomassa. Status kerusakan tanah adalah kondisi tanah di tempat dan waktu tertentu yang dinilai berdasarkan kriteria baku kerusakan tanah untuk produksi biomassa. Sementara itu, PP (2000) mendefisikan biomassa sebagai tumbuhan yang terdiri dari bunga, biji, buah, daun, ranting, batang, akar, termasuk tanaman hasil kegiatan pertanian, perkebunan, dan perhutanan. Selanjutnya, produksi biomassa didefisikan sebagai bentuk-bentuk pemanfaatan sumberdaya tanah untuk menghasilkan biomassa.

Berdasarkan paparan di atas, maka diperlukan semacam pendataan kerusakan tanah melalui pemetaan potensi dan status kerusakan tanah di SPK Sawangan Depok sebagai salah satu acuan untuk tindak lanjut peningkatan, pemeliharaan, pelestarian serta perbaikan kualitas tanah. Tujuan kajian ini adalah melakukan pemetaan dan strategi kebijakan dampak kerusakan tanah untuk produksi biomasa di kawasan Depok.

\section{METODE}

Secara geografis kota Depok terletak di antara $06^{\circ} 19^{\prime} 0^{\prime \prime}-06^{\circ} 28^{\prime} 0^{\prime \prime}$ Lintang Selatan dan $106^{\circ} 43^{\prime} 0^{\prime \prime}$ - 106 $55^{\circ} 0^{\prime \prime}$ Bujur Timur. Luas Kota Depok 200,29 km² yang mencakup 11 kecamatan salah satunya adalah Kecamatan Sawangan dengan luas 29,59 $\mathrm{km}^{2}$. Metode yang digunakan adalah metode survei yaitu melakukan pengamatan lahan secara langsung dan pengambilan sampel tanah 5 titik di SPK Sawangan. Peta yang disajikan dalam kajian ini menggunakan skala pemetaan 1:40.000. Selanjutnya pada analisis strategi kebijakan data dianalisis secara deskriptif melalui pendekatan interpretasi kuantitatif. 
Jurnal Pendidikan Geografi:

Kajian, Teori, dan Praktik dalam Bidang Pendidikan dan Ilmu Geografi

Volume 25, Nomor 2, Jun 2020, Hal 114-127

Pelaksanaan identifikasi kerusakan tanah untuk produksi biomassa SPK Sawangan, mengacu kepada 4 tahapan analisis yaitu peta kondisi awal tanah, potensi kerusakan, verifikasi lapangan, dan pemetaan status kerusakan tanah untuk biomassa (Permen LH, 2006). Penyusunan rencana, kebijakan dan program terkait hasil analisis kerusakan tanah SPK Sawangan dirancang dengan pendekatan model interpretasi terstruktur atau ISM. ISM (interpretative structural modelling) digunakan untuk menggambarkan permasalahan yang bersifat abstrak sehingga dapat lebih terstruktur. Tahapan yang dilakukan adalah dengan menginventarisasi kendala dalam implementasi alokasi lahan hutan untuk pertanian. Berdasarkan kendala yang telah tersusun tahap selanjutnya adalah memberikan penilaian perbandingan dengan VAXO, analisis terhadap output ISM berupa pemetaan permasalahan dan strukturisasi permasalahan. Skenario kendala dominan dilihat sebagai alternatif masukan dalam kebijakan dan strategi. Analisis ISM dapat memetakan dan menstrukturkan permasalahan yang bersifat abstrak menjadi lebih mudah dipahami tetapi pemahaman terhadap penilaian dengan VAXO perlu diperhatikan secara seksama dalam menilainya. Tahapan dalam melakukan ISM dibagi menjadi dua bagian, yaitu Penyusunan hirarki dan Klasifikasi sub elemen (Sushil, 2012). Penyusunan hirarki meliputi penentapan hubungan kontekstual antara sub elemen pengarahan (direction) atau yang menuju pada perbandingan berpasangan (oleh pakar). Penilaian hubungan kontekstual pada matriks perbandingan berpasangan. Tahapan selanjutnya, dilakukan klasifikasi sub elemen yang digolongkan dalam 4 sektor yaitu: (a) Sektor I; weak driver-weak dependent variabels (Autonomous). Sub elemen yang masuk dalam sektor ini umumnya tidak berkaitan dengan sistem, dan mungkin mempunyai hubungan sedikit, meskipun hubungan tersebut bisa saja kuat; (b) Sektor II; weak driver-strongly dependent variabels (Dependent). Umumnya sub elemen yang masuk dalam sektor ini adalah sub elemen yang tidak bebas; (c) Sektor III; strong driver-strongly dependent variabels (Linkage). Sub elemen yang masuk dalam sektor ini harus dikaji secara hati-hati, sebab hubungan antara elemen tidak stabil. Setiap tindakan pada sub elemen akan memberikan dampak terhadap sub elemen lainnya dan pengaruh umpan baliknya dapat memperbesar dampak; dan (d) Sektor IV; strong driver-weak dependent variabels (Independent). Sub elemen yang masuk dalam sektor ini merupakan bagian sisa dari sistem dan disebut peubah bebas.

\section{HASIL DAN PEMBAHASAN}

Penggunaan lahan di SPK Sawangan didominasi oleh penggunaan lahan tegalan/ ladang yaitu sebesar 1.690,82 Ha atau setara dengan 36,94\% dari luas keseluruhan. Penggunaan lahan dominan kedua adalah penggunaan lahan permukiman dengan luasan seluas $1.647,59 \mathrm{Ha}$ atau setara dengan $36,00 \%$. Sedangkan penggunaan lahan terendah adalah penggunaan lahan sebagai bangunan yaitu sebesar 1,06 Ha atau setara dengan $0,02 \%$ dari total luas keseluruhan. Penggunaan lahan pada SPK Sawangan terdiri dari 9 jenis yang disajikan berdasarkan luasan pada Tabel 1 .

\section{Peta Kondisi Awal Kerusakan Tanah}

Identifikasi kondisi awal kerusakan tanah dengan pembobotan skoring dan overlay peta dasar yang mencakup iklim, topografi, tata guna lahan, kemiringan lereng lahan dan jenis tanah. Pada tiap variabel peta dasar, masing-masing diberi bobot dan rating sehingga menghasilkan skor. Proses skoring setiap peta dasar ditentukan oleh ketentuan skoring yang ada dalam pedoman teknis penyusunan peta status kerusakan tanah untuk produksi biomassa tahun 2009. Ketentuan skoring tersebut disesuaikan dengan kondisi peta-peta dasar yang ada di SPK Sawangan, sehingga didapatkan hasil skoring setiap peta tematik yang sudah di overlay. Secara union menghasilkan satu peta baru yaitu peta potensi kerusakan awal lahan. 
Jurnal Pendidikan Geografi:

Kajian, Teori, dan Praktik dalam Bidang Pendidikan dan Ilmu Geografi

Volume 25, Nomor 2, Jun 2020, Hal 114-127

Tabel 1. Luas Penggunaan Lahan di SPK Sawangan

\begin{tabular}{clrc}
\hline \multirow{2}{*}{ No } & \multirow{2}{*}{ Penggunaan Lahan } & Luas & Ha \\
\cline { 3 - 4 } & Air/Perairan & 32,23 & 0,70 \\
2 & Bangunan & 1,06 & 0,02 \\
3 & Empang & 17,71 & 0,39 \\
4 & Kebun/Perkebunan & 506,79 & 11,07 \\
5 & Permukiman & $1.647,59$ & 36,00 \\
6 & Sawah Irigasi & 308,82 & 6,75 \\
7 & Sawah Tadah Hujan & 187,97 & 4,11 \\
8 & Semak/Belukar & 14,64 & 0,32 \\
9 & Tanah Kosong & 169,29 & 3,70 \\
10 & Tegalan/Ladang & $1.690,82$ & 36,94 \\
\hline Total Luas & & $\mathbf{4 . 5 7 6 , 9 2}$ & $\mathbf{1 0 0 , 0 0}$ \\
\hline
\end{tabular}

Sumber: RTRW Kota Depok 2012-2032

Tabel 2. Luas Potensi Awal Kerusakan Tanah SPK Sawangan

\begin{tabular}{|c|c|c|c|}
\hline \multirow{2}{*}{ Potensi Kerusakan } & \multirow{2}{*}{ Lokasi } & \multicolumn{2}{|c|}{ Luas } \\
\hline & & $\mathrm{Ha}$ & $\%$ \\
\hline \multirow{4}{*}{ Sedang } & Cinangka & 93,49 & 2,04 \\
\hline & Kedaung & 20,86 & 0,46 \\
\hline & Pondok Petir & 10,63 & 0,23 \\
\hline & Serua & 29,28 & 0,64 \\
\hline \multirow{13}{*}{ Tinggi } & Bedahan & 431,97 & 9,44 \\
\hline & Bojongsari Baru & 105,86 & 2,31 \\
\hline & Bojongsari Lama & 73,34 & 1,60 \\
\hline & Cinangka & 149,55 & 3,27 \\
\hline & Curug & 290,77 & 6,35 \\
\hline & Duren Mekar & 108,97 & 2,38 \\
\hline & Duren Seribu & 178,40 & 3,90 \\
\hline & Kedaung & 94,22 & 2,06 \\
\hline & Pasir Putih & 316,41 & 6,91 \\
\hline & Pengasihan & 328,72 & 7,18 \\
\hline & Pondok Petir & 167,97 & 3,67 \\
\hline & Sawangan Baru & 166,20 & 3,63 \\
\hline & Sawangan Lama & 203,64 & 4,45 \\
\hline \multirow{15}{*}{ Sangat Tinggi } & Serua & 179,47 & 3,92 \\
\hline & Bedahan & 159,12 & 3,48 \\
\hline & Bojongsari Baru & 93,82 & 2,05 \\
\hline & Bojongsari Lama & 66,15 & 1,45 \\
\hline & Cinangka & 103,10 & 2,25 \\
\hline & Curug & 142,20 & 3,11 \\
\hline & Duren Mekar & 107,47 & 2,35 \\
\hline & Duren Seribu & 139,35 & 3,04 \\
\hline & Kedaung & 108,36 & 2,37 \\
\hline & Pasir Putih & 157,35 & 3,44 \\
\hline & Pengasihan & 133,14 & 2,91 \\
\hline & Pondok Petir & 119,00 & 2,60 \\
\hline & Sawangan Baru & 114,01 & 2,49 \\
\hline & Sawangan Lama & 70,41 & 1,54 \\
\hline & Serua & 113,69 & 2,48 \\
\hline Total Luas & & $4.576,92$ & 100 \\
\hline
\end{tabular}


Jurnal Pendidikan Geografi:

Kajian, Teori, dan Praktik dalam Bidang Pendidikan dan Ilmu Geografi

Volume 25, Nomor 2, Jun 2020, Hal 114-127

Hasil analisis menunjukkan bahwa terdapat beberapa wilayah di SPK Sawangan, kondisi awal dibagi menjadi 3 kategori, yaitu sedang, tinggi, dan sangat tinggi. Potensi kerusakan yang termasuk ke dalam kategori sedang memiliki luasan terendah yakni seluas 154,26 ha atau setara dengan 3,37\% yang tersebar di 4 kelurahan. Potensi kerusakan yang termasuk ke dalam kategori tinggi memiliki luasan 2.795,49 ha yang tersebar di 14 kelurahan. Luasan ini termasuk luasan tertinggi dengan persentase sebesar $60,08 \%$ dari total luas keseluruhan. Sedangkan potensi kerusakan yang termasuk ke dalam kategori sangat tinggi memiliki luas $1.6227,17$ ha atau seluas $35,55 \%$ yang tersebar di 14 kelurahan. Hasil selengkapnya tersaji pada Tabel 2. Sebaran spasial ketiga kelas wilayah potensi awal kerusakan tanah dapat dilihat pada Gambar 1. Peta yang berisi informasi dugaan potensi kerusakan tanah menjadi dasar penentuan titik lokasi verifikasi lapangan berupa pengamatan dan pengambilan sampel tanah yang sebelumnya telah dijelaskan pada inventarisasi data. Kategori kerusakan tanah sedang tersebar di daerah bagian utara SPK Sawangan. Sedangkan kategori kerusakan lahan tinggi dan sangat tinggi tersebar merata. Menurut Firmansyah dan Sukwika (2020) kerusakan lahan yang terdapat di zonasi SPK Sawangan tidak sama tergantung pada tata guna lahan, jenis tanah yang tersedia, dan zat pembatas.

\section{Peta Potensi Kerusakan Tanah}

Peta kerusakan tanah yang sudah di-overlay dengan peta ruang dijadikan sebagai peta awal kerusakan lahan di SPK Sawangan. Potensi areal kerja efektif memiliki luasan seluas $2.899,59 \mathrm{Ha}$ atau setara dengan $63,35 \%$ yang tersebar di 14 kelurahan. Sedangkan daerah yang tidak efektif adalah kawasan budidaya seperti permukiman dan perikanan yang memiliki luasan seluas $1.677,33 \mathrm{Ha}$ atau setara dengan $36,65 \%$ dari total luas keseluruhan yang tersebar di 14 kelurahan. Potensi areal kerja efektif ini merupakan kawasan budidaya dan lindung yang dapat dijadikan sebagai pengembangan/produksi biomassa yaitu kawasan pertanian, perkebunan dan perhutanan (Firmansyah dan Sukwika, 2020). Luas dan lokasi potensi areal kerja di SPK Sawangan kota Depok disajikan dalam Tabel 3.

\section{Verifikasi Lapangan}

Kegiatan verifikasi untuk pembuktian ada tidaknya indikasi atau potensi terjadinya kerusakan tanah pada areal kerja efektif dengan potensi kerusakan paling tinggi sebagai prioritas utamanya. Hasil peta kondisi awal tanah dan peta ruang SPK

Sawangan dipergunakan sebagai areal kerja efektif pengambilan sampel tanah. Peta potensi kerja efektif pada SPK Sawangan dapat dilihat pada Gambar 2.

Peta titik observasi adalah peta kerusakan tanah yang didalamnya terdapat statusstatus potensi kerusakan ditambah dengan adanya persebaran 5 titik sampel. Sebaran 5 titik sampel didasarkan pada status kerusakan yaitu status sedang dan tinggi. Peta titik pengambilan sampel tanah SPK Sawangan dapat dilihat pada Gambar 3. Penentuan kondisi awal tanah berdasarkan hasil overlay beberapa peta tematik lahan, yaitu lereng, curah hujan, penggunaan lahan, dan jenis tanah. Sedangkan data karakteristik fisik pada 5 titik pengamatan yang diamati di SPK Sawangan disajikan pada Tabel 4.

\section{Peta Status Kerusakan Tanah}

Peta status kerusakan tanah untuk produksi biomasa merupakan output akhir tentang status, sebaran dan luasan kerusakan tanah pada wilayah yang dipetakan. Status kerusakan tanah didasarkan hasil verifikasi pengambilan sampel dan analisis sampel tanah di laboratorium. Berdasarkan Tabel 5, analisis pada lokasi SPK Sawangan berkategori status rusak sedang dan tinggi. 
Jurnal Pendidikan Geografi:

Kajian, Teori, dan Praktik dalam Bidang Pendidikan dan Ilmu Geografi

Volume 25, Nomor 2, Jun 2020, Hal 114-127

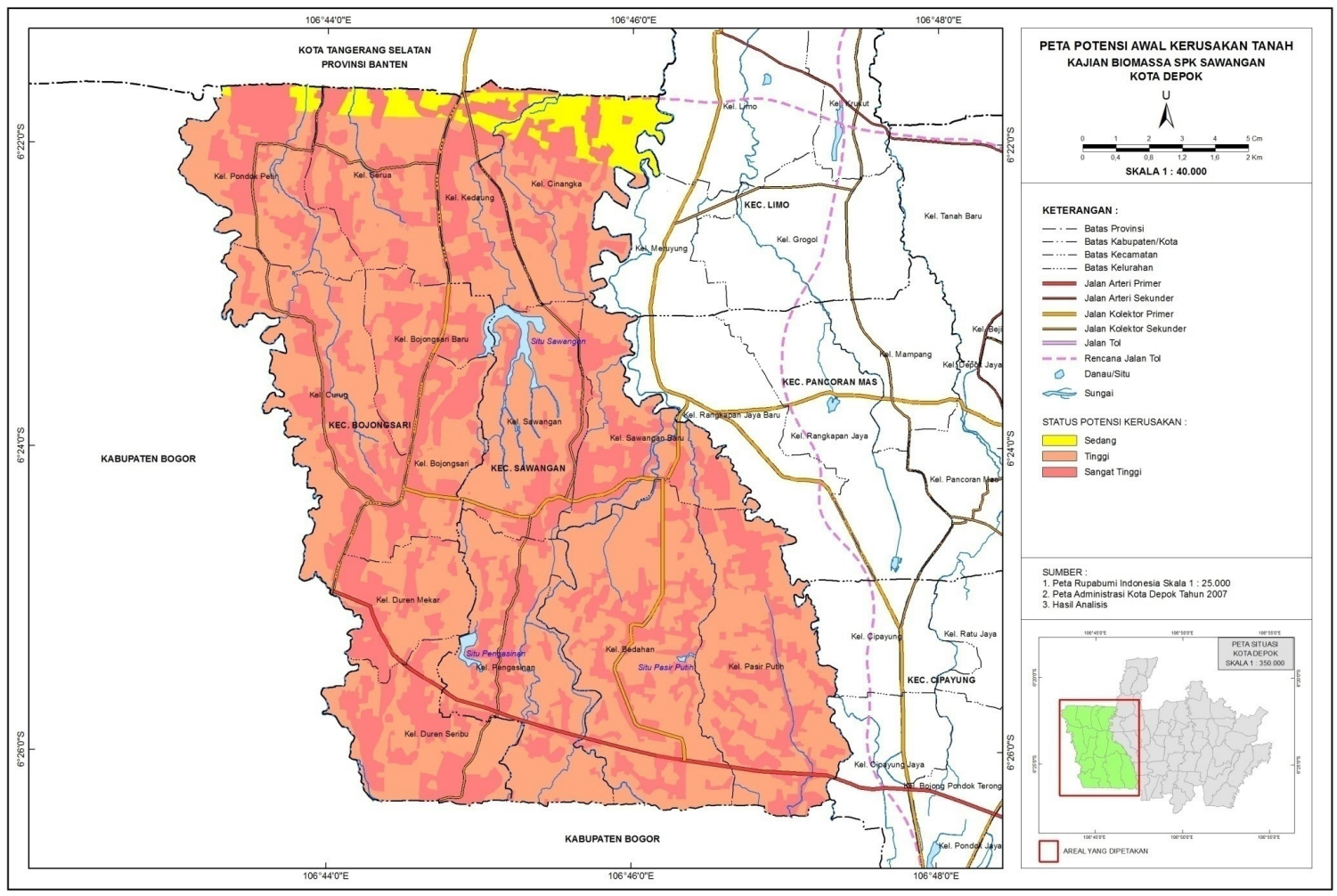

Gambar 1. Peta Potensi Awal Kerusakan Tanah SPK Sawangan

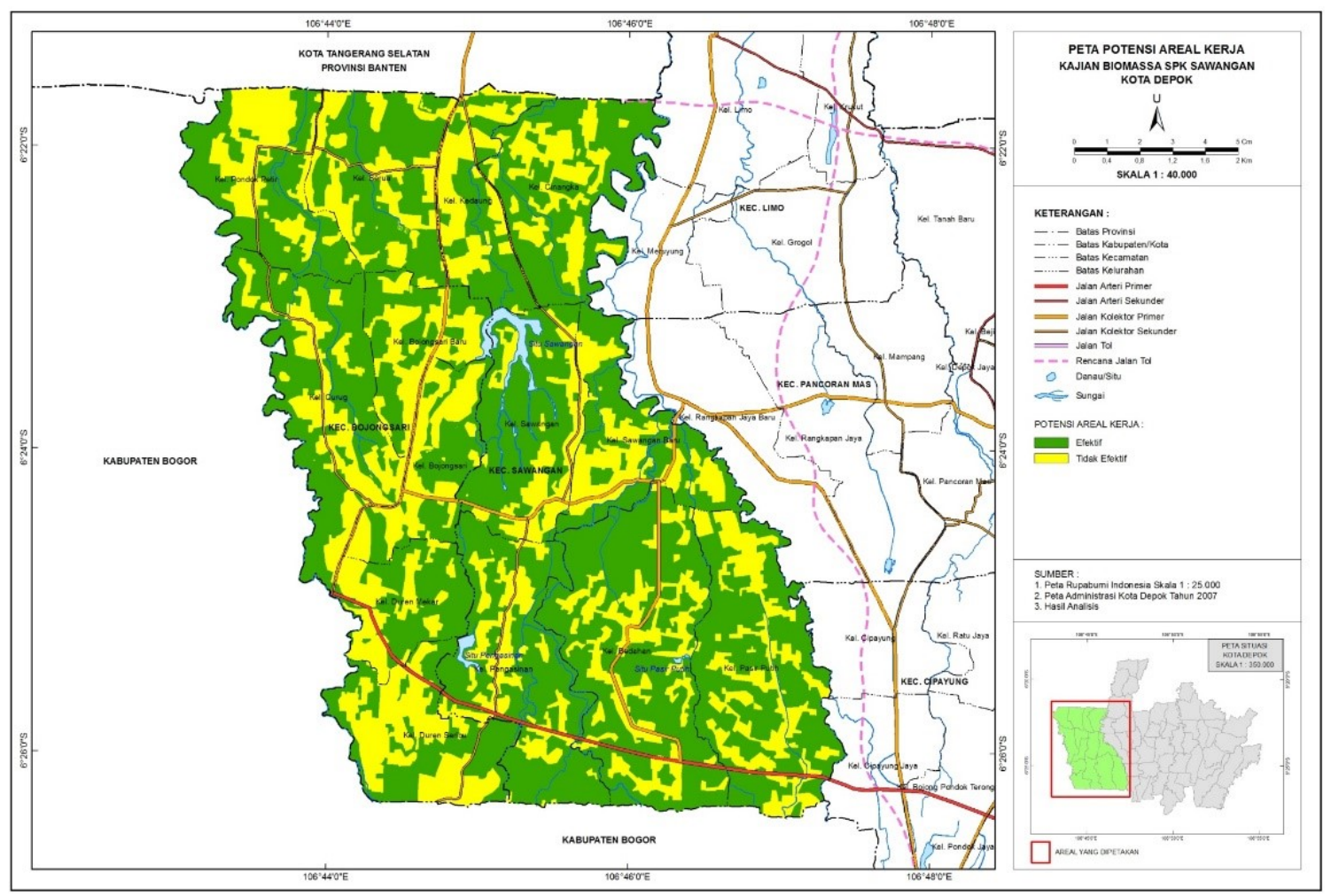

Gambar 2. Peta Potensi Areal Kerja SPK Sawangan 
Jurnal Pendidikan Geografi:

Kajian, Teori, dan Praktik dalam Bidang Pendidikan dan Ilmu Geografi

Volume 25, Nomor 2, Jun 2020, Hal 114-127

Tabel 3. Luas Potensi Areal Kerja SPK Sawangan

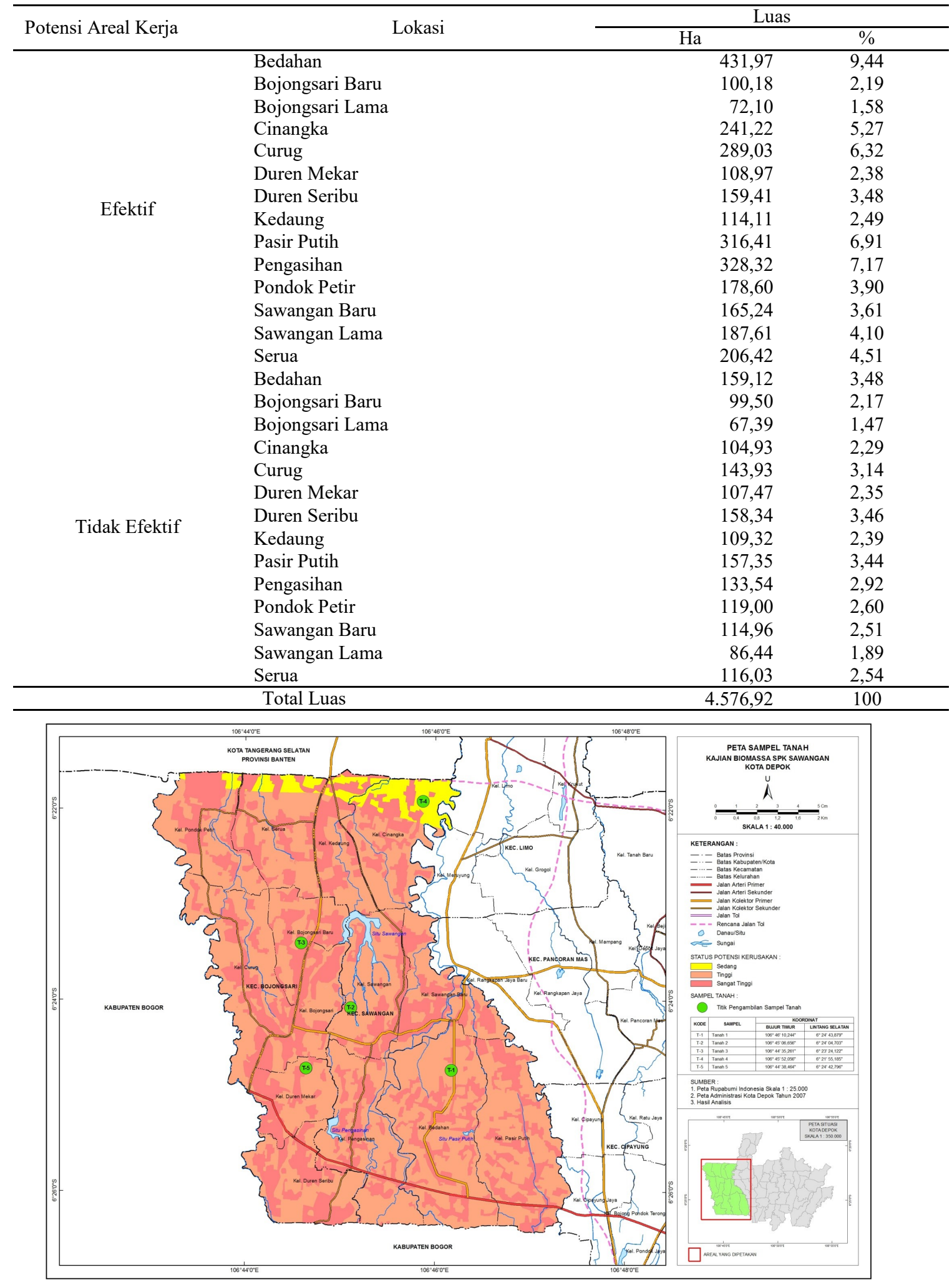

Gambar 3. Peta Titik Sampel Tanah SPK Sawangan 
Jurnal Pendidikan Geografi:

Kajian, Teori, dan Praktik dalam Bidang Pendidikan dan Ilmu Geografi

Volume 25, Nomor 2, Jun 2020, Hal 114-127

Tabel 4. Data Karakteristik Fisik Lahan di SPK Sawangan

\begin{tabular}{|c|c|c|c|c|c|c|c|}
\hline \multirow{2}{*}{$\begin{array}{l}\text { Kode } \\
\text { Titik } \\
\text { Sampel }\end{array}$} & \multirow{2}{*}{$\begin{array}{l}\text { Lokasi } \\
\text { Sampel }\end{array}$} & \multicolumn{2}{|l|}{ Koordinat } & \multirow{2}{*}{$\begin{array}{l}\text { Lereng } \\
(\%)\end{array}$} & \multirow{2}{*}{$\begin{array}{l}\text { Curah } \\
\text { Hujan }(\mathrm{mm} / \\
\text { th) }\end{array}$} & \multirow{2}{*}{ Penggunaan Lahan } & \multirow{2}{*}{$\begin{array}{l}\text { Jenis } \\
\text { Tanah }\end{array}$} \\
\hline & & $\begin{array}{l}\text { Bujur } \\
\text { Timur }\end{array}$ & $\begin{array}{l}\text { Lintang } \\
\text { Selatan } \\
\end{array}$ & & & & \\
\hline $\mathrm{T}-1$ & Bedahan & 106.7695 & -6.411 & $8-15$ & $2500-3000$ & Tegalan/ Ladang & LM, LCK \\
\hline $\mathrm{T}-2$ & $\begin{array}{l}\text { Sawangan } \\
\text { Lama }\end{array}$ & 106.7517 & -6.401 & $8-15$ & $2500-3000$ & Tanah Kosong & LM, LCK \\
\hline $\mathrm{T}-3$ & $\begin{array}{l}\text { Bojongsari } \\
\text { Baru }\end{array}$ & 106.7432 & -6.389 & $8-15$ & $2500-3000$ & Tegalan/ Ladang & LM, LCK \\
\hline $\mathrm{T}-4$ & Cinangka & 106.7646 & -6.365 & $8-15$ & $2000-2500$ & Tegalan/ Ladang & LM, LCK \\
\hline $\mathrm{T}-5$ & Duren Mekar & 106.7438 & -6.411 & $8-15$ & $2500-3000$ & Sawah Tadah Hujan & LM, LCK \\
\hline
\end{tabular}

Keterangan: LM (Latosol Merah); LCK (Latosol Coklat Kemerahan)

Tabel 5. Hubungan Status Kerusakan Tanah dengan Penggunaan Lahan

\begin{tabular}{|c|c|c|c|c|c|c|}
\hline \multirow[t]{2}{*}{ Status } & \multirow[t]{2}{*}{ Pembatas } & \multirow[t]{2}{*}{ PL } & \multicolumn{2}{|l|}{ Luas } & \multirow[t]{2}{*}{ Penggunaan Lahan } & \multirow[t]{2}{*}{ Lokasi } \\
\hline & & & $\mathrm{Ha}$ & $\%$ & & \\
\hline \multirow[t]{3}{*}{ Sedang } & Bobot isi & 1 & 2,01 & 0,07 & $\begin{array}{l}\text { Kebun/Perkebunan, Tegalan/ } \\
\text { Ladang }\end{array}$ & Pondok Petir \\
\hline & & 5 & 109,66 & 3,81 & $\begin{array}{l}\text { Kebun/Perkebunan, Sawah Irigasi, } \\
\text { Tegalan/Ladang }\end{array}$ & Kedaung; Cinangka; Serua \\
\hline & & 8 & 30,22 & 1,05 & $\begin{array}{l}\text { Kebun/Perkebunan, Tegalan/ } \\
\text { Ladang }\end{array}$ & Cinangka \\
\hline Jumlah & & & 141,89 & 4,93 & & \\
\hline \multirow[t]{9}{*}{ Tinggi } & $\begin{array}{l}\text { Permea- } \\
\text { bilitas }\end{array}$ & 6 & 6,04 & 0,21 & Tanah Kosong & $\begin{array}{l}\text { Kedaung; Serua; Sawangan; } \\
\text { Pondok Petir }\end{array}$ \\
\hline & & 20 & 140,75 & 4,89 & Tanah Kosong & $\begin{array}{l}\text { Sawangan; Kedaung; Bedahan } \\
\text { Pengasinan; Pasir Putih; Bo- } \\
\text { jong-sari; Bojongsari Baru; } \\
\text { Serua; Curug; Duren Mekar }\end{array}$ \\
\hline & & 14 & 6,33 & 0,22 & Tanah Kosong & $\begin{array}{l}\text { Curug; Duren Mekar; Duren } \\
\text { Seribu }\end{array}$ \\
\hline & & 13 & 10,36 & 0,36 & Tanah Kosong & $\begin{array}{l}\text { Cinangka; Sawangan Baru; } \\
\text { Pasir Putih; Duren Seribu }\end{array}$ \\
\hline & Keasaman & 2 & 2,015 & 0,07 & Semak/Belukar & Pondok Petir \\
\hline & & 8 & 12,09 & 0,42 & Semak/Belukar & Duren Seribu, Serua \\
\hline & & 9 & $2.170,55$ & 75,41 & $\begin{array}{l}\text { Kebun/Perkebunan, Sawah Irigasi, } \\
\text { Sawah Tadah Hujan, Tegalan/ } \\
\text { Ladang }\end{array}$ & $\begin{array}{l}\text { Kedaung; Cinangka; } \\
\text { Sawangan Baru; Bedahan; } \\
\text { Pengasinan; Pasir Putih; Bo- } \\
\text { jong-sari; Bojongsari Baru; } \\
\text { Serua; Pondok Petir; Curug; } \\
\text { Duren Mekar; Duren Seribu }\end{array}$ \\
\hline & & 2 & 159,46 & 5,54 & $\begin{array}{l}\text { Kebun/Perkebunan, Tegalan/ } \\
\text { Ladang }\end{array}$ & $\begin{array}{l}\text { Sawangan; Cinangka; } \\
\text { Sawangan Baru; Pasir Putih }\end{array}$ \\
\hline & Bobot Isi & 3 & 229,12 & 7,96 & $\begin{array}{l}\text { Kebun/Perkebunan, Sawah Irigasi, } \\
\text { Sawah Tadah Hujan, Tegalan/ } \\
\text { Ladang }\end{array}$ & Pondok Petir; Duren Seribu \\
\hline Jumlah & & & $2.736,72$ & 95,07 & & \\
\hline
\end{tabular}


Jurnal Pendidikan Geografi:

Kajian, Teori, dan Praktik dalam Bidang Pendidikan dan Ilmu Geografi

Volume 25, Nomor 2, Jun 2020, Hal 114-127

Setiap titik contoh (sampling) mempunyai pembatas sesuai hasil analisis dengan metode matching. Secara keseluruhan, lahan yang termasuk kedalam status kerusakan sedang memiliki luasan seluas 141,89 ha yang terdiri dari SPL 1, SPL 5, dan SPL 8. Sedangkan lahan yang termasuk kategori status kerusakan tanah tinggi memiliki luasan 2.736,72 ha yang terdiri dari SPL 2, SPL 13, SPL 14, SPL 18, SPL 23, SPL 6, SPL 12, SPL 19, SPL 20, dan SPL 22. Variabel pembatas pada SPL 1, SPL 8, SPL 5, SPL 13 adalah bobot isi. Pada SPL 2, SPL 14, SPL 23, SPL 6, dan SPL 20 memiliki variabel pembatas permeabilitas. Serta pada SPL 18, SPL 12, SPL 19, dan SPL 22 memiliki variabel pembatas keasaman. Prasetyo dan Thohiron (2013) menggunakan parameter pembatas serupa dan diketahui terdapat seluas 2.052 hektar yang berpotensi mengalami kerusakan tanah kategori tinggi.

Penetapan status kerusakan tanah didasarkan pada nilai frekuensi relatif. Hasil penilaian diketahui parameter ketebalan solum, batuan permukaan, parameter $\mathrm{pH}$, daya hantar listrik, komposisi fraksi pasir, porositas total, dan mikroba masih dalam kategori diambang batas. Sebaran spasial status kerusakan tanah tersaji pada Gambar 4. Status kerusakan tanah sedang dengan pembatas bobot isi tersebar di bagian utara lokasi SPK Sawangan. Kategori status kerusakan tanah tinggi dengan pembatas permeabilitas, keasaman dan bobot isi tersebar hampir di seluruh bagian lokasi SPK Sawangan. Kondisi diatas sejalan dengan hasil penelitian Firmansyah dan Sukwika (2020) yang menyebutkan bahwa parameter yang paling berpengaruh dalam kerusakan lahan di SPK Sawangan ini adalah bobot isi, permeabilitas, dan kemasaman. Menurut Firmansyah dan Sukwika (2020) nilai bobot isi tanah berbanding lurus dengan tingkat kekasaran partikel tanah, makin lembut akan makin ringan. Permeabilitas dipengaruhi selain oleh tekstur, struktur tanah juga oleh porositas tanah (Permen LH, 2006). Tanah berporositas total besar akan berbanding lurus dengan laju infiltrasi yang tinggi, begitu juga ketebalan mempengaruhi solum kemampuan tanah dalam meluluskan air (Sukisno et al., 2011).

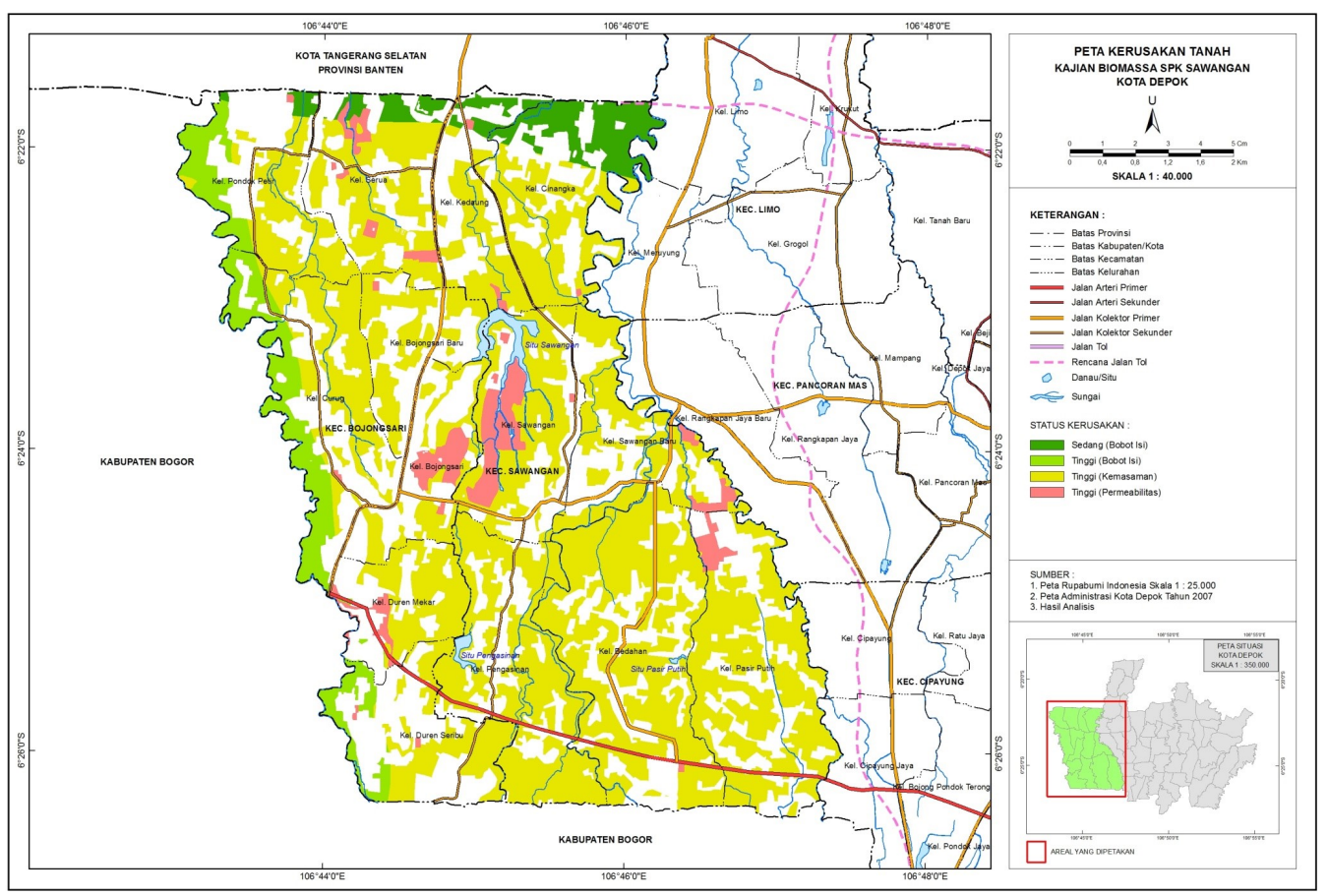

Gambar 4. Hierarki Peta Kerusakan Tanah SPK Sawangan 
Jurnal Pendidikan Geografi:

Kajian, Teori, dan Praktik dalam Bidang Pendidikan dan Ilmu Geografi

Volume 25, Nomor 2, Jun 2020, Hal 114-127

Upaya perbaikan lahan dengan faktor pembatas bobot isi dan permeabilitas dapat dengan menambahkan bahan organik. Bahan organik dapat meningkatkan pori di dalam tanah sehingga nilai bobot isi dapat berkurang dan kemampuan tanah meloloskan air dapat diperbaiki (Firmansyah dan Sukwika, 2020; Sumarno et al., 2015).

Persentase luasan kategori tanah rusak sedang tertinggi berada pada SPL 5 dengan pembatas bobot isi yang tersebar di daerah Kedaung, Cinangka, dan Serua dengan nilai sebesar 3,81\%. Persentase luasan terendah pada SPL 1 tersebar di kelurahan Pondok Petir dengan nilai sebesar $0,07 \%$. Pada status kerusakan tinggi, luasan yang memiliki nilai tertinggi ada di SPL 19 (75,41\%) dengan pembatas kemasaman yang tersebar di kelurahan Bedahan, Bojongsari, Bojongsari Baru, Cinangka, Curug, dan Duren Mekar, Duren Seribu Kedaung, Sawangan Baru, Serua, Pengasinan, Pasir Putih, Pondok Petir. Perbaikan faktor pembatas kemasaman tanah dengan pengapuran seperti dolomit dan calsit dan pemberian bahan organik atau kompos (Darma, 2017; Darmawijaya, 2014; Hanafiah, 2018).

\section{Strategi Kebijakan Dampak Kerusakan Tanah SPK Sawangan}

Berdasarkan hasil analisis kerusakan tanah untuk produksi biomassa di SPK Sawangan yang telah dilakukan sebelumnya, diperoleh beberapa kendala kerusakan tanah. Keseluruhan kendala dalam kerusakan tanah untuk produksi biomassa tersebut disajikan pada Tabel 6.

Tabel 6. Kendala Kerusakan Tanah untuk Produksi Biomassa SPK Sawangan

\begin{tabular}{ll}
\hline No & Sub Elemen Kendala \\
\hline E1 & Pengurangan penggunaan pupuk kimia secara berlebihan \\
E2 & Penerapan pengapuran sebelum masa tanam \\
E3 & Pemanfaatan luasan lahan terbuka dengan vegetasi \\
E4 & Pengurangan menggunakan lahan secara intensif \\
E5 & Penerapan penggunaan pupuk organik untuk pertanian berkelanjutan \\
E6 & Penggalakan mengurangi alat berat pada lahan sawah \\
\hline
\end{tabular}

\begin{tabular}{|c|}
\hline $\begin{array}{c}\text { Penggalakan mengurangi } \\
\text { alat berat pada lahan } \\
\text { sawah [E6] }\end{array}$ \\
\hline Jangka Panjang \\
\hline
\end{tabular}

III

\begin{tabular}{|c|}
\hline $\begin{array}{c}\text { Pemanfaatan luasan lahan } \\
\text { terbuka dengan vegetasi } \\
{[\mathrm{E} 3]}\end{array}$ \\
\hline Jangka Menengah \\
\hline
\end{tabular}
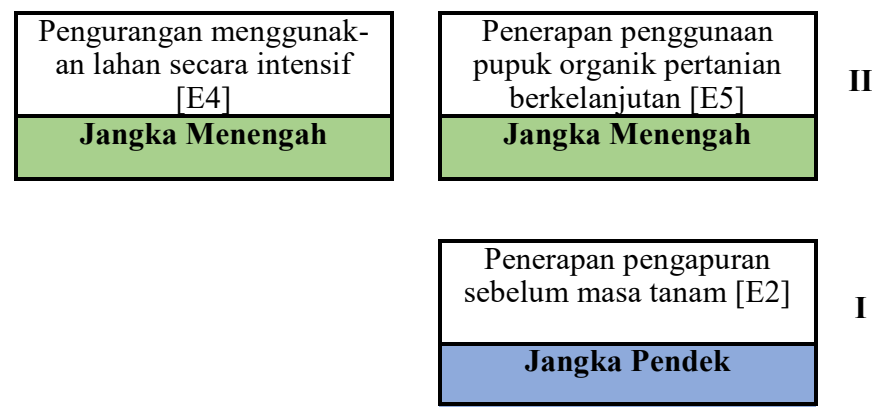

Gambar 5. Hirarki Kendala Analisis Kerusakan Tanah untuk Produksi Biomassa SPK Sawangan 
Jurnal Pendidikan Geografi:

Kajian, Teori, dan Praktik dalam Bidang Pendidikan dan Ilmu Geografi

Volume 25, Nomor 2, Jun 2020, Hal 114-127

Hasil analisis dari kendala-kendala tersebut diperoleh status tingkat daya pengaruh dan daya pendorongnya yang ditunjukkan berdasarkan informasi pada kuadran independent, linkage, dependent dan autonomous. Faktor yang berada pada kuadran independent memiliki pengaruh besar terhadap faktor lain yang berada pada kuadran dependent dan linkage. Berdasarkan kuadran tersebut diperoleh hirarki untuk membagi tahapan pengelolaan berjangka. Hirarki tersebut disajikan pada Gambar 5.

Berdasarkan hirarki alternatif kebijakan dengan mempertimbangkan permasalahan dan kendala, maka prioritas faktor independent (hirarki I) adalah fokus pada pengurangan penggunaan pupuk kimia secara berlebihan (E1), dan perlu penerapan pengapuran sebelum masa tanam terutama pada lahan sawah dan tegalan (E2). Dampak penggunaan pupuk kimia berakibat pada masalah lingkungan, kesuburan biologis, dan kondisi fisik tanah (Dewanto et al., 2013). Menurut Cronin (2019) penggunaan kapur mendorong kegiatan mikroorganisme tanah sehingga proses dekomposisi mengalami peningkatan. Perlakuan kapur sebelum masa tanam dapat meningkatkan pertumbuhan vegetatif, ketersediaan unsur-unsur hara (Nurhayati, 2011), dan terpenting dari pengapuran adalah untuk menunjang pertumbuhan dan perkembangan dan produktivitas tanaman (Firmansyah dan Sukwika, 2020). Faktor linkage (hirarki II) terdiri dari; pemanfaatan luasan lahan terbuka dengan vegetasi pada lahan kosong (E3), mengurangi penggunaan lahan secara intensif (E4), serta penerapan penggunaan pupuk untuk pertanian berkelanjutan (E5). Produktivitas lahan pada lahan kosong atau gontai dapat dimanfaatkan dengan ditanami tumbuhan produktif melalui pendekatan pengelolaan urban forestry (Sukwika et al., 2020). Penggunaan teknologi yang sesuai berpengaruh pada penggurangan intensitas penggunaan lahan yang dapat menekan lahan (human-burdened land). Jika ini dilakukan secara berkelanjutan maka tercipta suatu penataan lahan yang lebih terorganisir secara alami (Baja, 2012). Menurut Dariah et al. (2015) penggunaan bahan organik efektif memperbaiki kualitas tanah dan produktivitas lahan, juga bersifat terbarukan, insitu, dan relatif murah, serta mendukung konservasi karbon dalam tanah. Terakhir, faktor dependent (hirarki III) adalah menggalakan pengurangan penggunaan alat berat pada lahan sawah (E6). Pemulihan lahan sawah dapat dilakukan dengan pengurangan pengunaan alat berat. Secara produktivitas, menurut Silamat et al. (2014) lahan sawah di perkotaan relatif sempit sehingga tidak ada perbedaan yang signifikan antara pengolahan lahan secara konvensional dan penggunaan alat berat. Berdasarkan hirarki alternatif kebijakan disusun strategi kebijakan kerusakan tanah di SPK Sawangan yang secara terperinci disajikan pada Tabel 7.

\section{KESIMPULAN}

Kerusakan lahan di SPK Sawangan mencakup kategori status kerusakan sedang dan tinggi. Hasil survei dan analisis laboratorium yang telah di matching dan scoring menunjukkan bahwa SPK Sawangan sebagian besar SPL termasuk kedalam status rusak tinggi. Berdasarkan hirarki alternatif kebijakan, perlu prioritas pengurangan penggunaan pupuk kimia yang berlebihan dan pengapuran sebelum masa tanam di lahan sawah dan tegalan. Rekomendasi kebijakan penanganan kerusakan tanah di SPK Sawangan dapat dijadikan sebagai lokasi pengembangan perkotaan dengan berbagai upaya perbaikan. Pengembangan perkotaan tersebut didasarkan pada status kerusakan tanah dan dialokasikan ke lokasi status kerusakan tanah sedang dengan status penggunaan lahan tegalan/ladang yang berada di Kelurahan Cinangka, Kedaung, Pondok Petir dan Serua. Lokasi pengembangan selanjutnya diarahkan ke status kerusakan tanah tinggi dengan status penggunaan lahan tanah kosong seperti di kelurahan Bedahan, Bojongsari, Bojongsari Baru, Cinangka, Curug, Duren Mekar, Duren Seribu, Kedaung, Sawangan, Serua, Pasir Putih, Pengasinan, dan Pondok Petir. 
Jurnal Pendidikan Geografi:

Kajian, Teori, dan Praktik dalam Bidang Pendidikan dan Ilmu Geografi

Volume 25, Nomor 2, Jun 2020, Hal 114-127

Tabel 7. Strategi Kebijakan pada Kerusakan Tanah di SPK Sawangan

\begin{tabular}{|c|c|c|c|c|}
\hline No & Kebijakan & Rencana & Program & $\begin{array}{l}\text { Dasar } \\
\text { Pertimbangan }\end{array}$ \\
\hline 1 & $\begin{array}{l}\text { Pemanfaatan } \\
\text { luasan lahan } \\
\text { terbuka dengan } \\
\text { vegetasi }\end{array}$ & $\begin{array}{l}\text { Menanam lahan } \\
\text { tanah kosong } \\
\text { dengan vegetasi } \\
\text { tanaman keras }\end{array}$ & $\begin{array}{l}\text { Pembagian bibit vegetasi tanaman keras ke lahan } \\
\text { tanah kosong: } \\
\text { Bedahan seluas } 1,08 \text { ha } \\
\text { Bojongsari Baru seluas } 0,92 \text { ha } \\
\text { Bojongsari Lama seluas } 27,59 \text { ha } \\
\text { Cinangka seluas } 0,56 \text { ha } \\
\text { Curug seluas } 1,17 \text { ha } \\
\text { Duren Mekar seluas } 13,33 \text { ha } \\
\text { Duren Seribu seluas } 1,59 \text { ha } \\
\text { Kedaung seluas } 3,9 \text { ha } \\
\text { Pasir Pustih seluas } 14,65 \text { ha } \\
\text { Pengasinan seluas } 1,28 \text { ha } \\
\text { Pondok Petir seluas } 0,82 \text { ha } \\
\text { Sawangan Baru seluas } 11,92 \text { ha } \\
\text { Sawangan Lama seluas } 59,19 \text { ha } \\
\text { Serua seluas } 22,07 \text { ha }\end{array}$ & $\begin{array}{l}\text { Meningkatkan } \\
\text { permeabilitas di } \\
\text { lahan tanah } \\
\text { kosong }\end{array}$ \\
\hline 2 & $\begin{array}{l}\text { Mengurangi } \\
\text { penanaman } \\
\text { secara intensif }\end{array}$ & $\begin{array}{l}\text { Melakukan } \\
\text { rotasi tanaman } \\
\text { Melakukan } \\
\text { pemberaan/ } \\
\text { penjedaan waktu } \\
\text { tanah } \\
\text { Melakukan } \\
\text { pengolahan } \\
\text { khusus pada } \\
\text { permukaan olah } \\
\text { tanah }\end{array}$ & $\begin{array}{l}\text { Sosialisasi kepada petani untuk melakukan rotasi } \\
\text { tanaman, misalnya menjadi padi-palawija-padi } \\
\text { Penyuluhan kepada petani untuk melakukan bera } \\
\text { tanah dari setelah masa panen hingga sebelum } \\
\text { masa tanam } \\
\text { Pendampingan petani untuk pengolahan yang baik } \\
\text { pada permukaan olah tanah sebelum masa tanam } \\
\text { Lokasi: } \\
\text { Cinangka; Duren Mekar; Kedaung; Duren Seribu; } \\
\text { Pondok Petir-; Serua }\end{array}$ & $\begin{array}{l}\text { Meningkatkan } \\
\text { bobot isi (BI) } \\
\text { pada lahan } \\
\text { kebun/ } \\
\text { perkebunan, } \\
\text { tegalan/ladang, } \\
\text { sawah }\end{array}$ \\
\hline 3 & $\begin{array}{l}\text { Menggalakan } \\
\text { pengurangan } \\
\text { alat berat pada } \\
\text { lahan sawah }\end{array}$ & $\begin{array}{l}\text { Mengubah } \\
\text { kebiasaan petani } \\
\text { untuk membajak } \\
\text { sawah tanpa alat } \\
\text { berat }\end{array}$ & $\begin{array}{l}\text { Sosialisasi hingga penyuluhan kepada petani } \\
\text { Lokasi: } \\
\text { Cinangka-; Duren Mekar; Kedaung; Duren Seribu; } \\
\text { Pondok Petir-; Serua }\end{array}$ & $\begin{array}{l}\text { Mengurangi } \\
\text { kepadatan tanah } \\
\text { pada lahan } \\
\text { sawah }\end{array}$ \\
\hline 4 & $\begin{array}{l}\text { Pengurangan } \\
\text { penggunaan } \\
\text { pupuk kimia } \\
\text { secara } \\
\text { berlebihan }\end{array}$ & $\begin{array}{l}\text { Mengganti } \\
\text { pupuk kimia } \\
\text { dengan kadar } \\
\text { yang lebih } \\
\text { rendah }\end{array}$ & $\begin{array}{l}\text { Pemberhentian subsidi pupuk dengan kadar kimia } \\
\text { yang tinggi }\end{array}$ & $\begin{array}{l}\text { Meningkatkan } \\
\text { kemasaman } \\
\text { tanah }(\mathrm{pH})\end{array}$ \\
\hline 5 & $\begin{array}{l}\text { Penerapan } \\
\text { penggunaan } \\
\text { pupuk organik } \\
\text { untuk pertanian } \\
\text { berkelanjutan }\end{array}$ & $\begin{array}{l}\text { Pengenalan } \\
\text { manfaat pupuk } \\
\text { organik }\end{array}$ & $\begin{array}{l}\text { Sosialisasi mengenai pupuk organik dan } \\
\text { manfaatnya yang berkelanjutan dibandingkan } \\
\text { pupuk kimia } \\
\text { Pendampingan pembuatan pupuk organik dari } \\
\text { penyuluh pertanian lepas (PPL) ke petani }\end{array}$ & $\begin{array}{l}\text { Meningkatkan } \\
\text { kemasaman } \\
\text { tanah }(\mathrm{pH})\end{array}$ \\
\hline 6 & $\begin{array}{l}\text { Penerapan } \\
\text { pengapuran } \\
\text { sebelum masa } \\
\text { tanam }\end{array}$ & $\begin{array}{l}\text { Pengenalan } \\
\text { manfaat } \\
\text { pengapuran }\end{array}$ & $\begin{array}{l}\text { Pemberian subsidi kapur ke petani } \\
\text { Sosialisasi pengapuran pada tanah bersamaan } \\
\text { dengan pemberian pupuk pasca tanam }\end{array}$ & $\begin{array}{l}\text { Meningkatkan } \\
\text { kemasaman } \\
\text { tanah }(\mathrm{pH})\end{array}$ \\
\hline
\end{tabular}


Jurnal Pendidikan Geografi:

Kajian, Teori, dan Praktik dalam Bidang Pendidikan dan Ilmu Geografi

Volume 25, Nomor 2, Jun 2020, Hal 114-127

\section{DAFTAR PUSTAKA}

Baja, S. (2012). Perencanaan tata guna lahan dalam pengembangan wilayah: pendekatan spasisal dan aplikasinya. Jakarta: Penerbit Andi.

BPS-Depok. (2018). Kota Depok dalam angka 2018. Depok: Badan Pusat Statistik.

Cronin, D. (2019). Soil Science: Conservation and nutrient management. Berlin: Callisto Reference.

Dariah, A., Sutono, S., Nurida, N. L., Hartatik, W., \& Pratiwi, E. (2015). Pembenah tanah untuk meningkatkan produktivitas lahan pertanian. Jurnal Sumberdaya Lahan, 9(2), 67-84. https://doi.org/10.2018/jsdl.v9i2.6571

Darma, S. (2017). Identifikasi status kerusakan tanah untuk produksi biomassa di kecamatan Tanjung Palas Timur kabupaten Bulungan provinsi Kaltara. ZIRAA'AH, 42(1), 8-16.

Darmawijaya, M. I. (2014). Dasar-dasar ilmu tanah. Jakarta: Rajawali Press.

Dewanto, F. G., Londok, J. J. M. R., Tuturoong, R. A. V., \& Kaunang, W. B. (2017). Pengaruh pemupukan anorganik dan organik terhadap produksi tanaman jagung sebagai sumber pakan. ZOOTEC, 32(5). https://doi.org/10.35792/zot.32.5.2013.982

El-Gammal, M. I., Ali, R. R., \& Abou Samra, R. M. (2015). GIS-based land degradation risk assessment of Damietta governorate, Egypt. Egyptian Journal of Basic and Applied Sciences, 2(3), 183-189. https://doi.org/10.1016/j.ejbas.2015.01.001

Firmansyah, I., \& Sukwika, T. (2020). Penilaian kondisi degradasi tanah di SPK Sawangan.

Firmansyah, I., \& Sukwika, T. (2020). Penilaian Kondisi Degradasi Tanah Di Spk Sawangan Kota Depok. Jurnal Tanah Dan Sumberdaya Lahan, 7(1), 45-57. https:// doi.org/10.21776/ub.jtsl.2020.007.1.7

Hanafiah, K. A. (2018). Dasar-dasar ilmu tanah (8th ed.). Jakarta: Rajawali Pers.

Nurhayati. (2011). Pengaruh jenis amelioran terhadap efektivitas dan infektivitas mikroba pada tanah gambut dengan kedelai sebagai tanaman indikator. J. Floratek, 6, 124-139. https://doi.org/10.24815/floratek.v6i2.506

Perda Depok, J. B. (2015). Peraturan Daerah Kota Depok No. 1 tentang Rencana tata ruang wilayah kota Depok tahun 2012-2032.

Permen LH, R. I. (2006). Peraturan Menteri Lingkungan Hidup No. 7 tentang Tata cara pengukuran kriteria baku kerusakan tanah untuk produksi biomassa.

Permen LH, R. I. (2008). Peraturan Menteri Lingkungan Hidup No. 20 tentang Petunjuk teknis standar pelayanan minimal bidang lingkungan hidup daerah kabupaten kota.

PP, R. I. (2000). Peraturan Pemerintah RI No. 105 tentang Pengendalian kerusakan tanah untuk produksi biomassa.

Prasetyo, H., \& Thohiron, M. (2013). Aplikasi SIG dalam penilaian status kerusakan tanah untuk produksi biomassa di Kabupaten Tuban, Jawa Timur. J-PAL, 4(1), 6368.

Setyani, W., Sitorus, S. R. P., \& Panuju, D. R. (2017). Analisis ruang terbuka hijau dan kecukupannya di Kota Depok. Buletin Tanah Dan Lahan, 1(1), 121-127.

Silamat, E., Yuwana, ., \& Yuliarso, M. Z. (2014). Analisis produktivitas usaha tani padi sawah dengan menggunakan traktor tangan dan cara konvensional di Kabupaten Rejang Lebong. Jurnal AGRISEP, 13(2), 197-215. https://doi.org/10.31186/ jagrisep.13.2.197-215.

Sukisno, Hindarto, K. S., Hasanudin, \& Wicaksono, A. H. (2011). Pemetaan potensi dan status kerusakan tanah untuk mendukung produktivitas biomassa di Kabupaten Lebong. In Prosiding Seminar Nasional Budidaya Pertanian Urgensi dan Strategi Pengendalian Alih Fungsi Lahan (pp. 140-157). 
Jurnal Pendidikan Geografi:

Kajian, Teori, dan Praktik dalam Bidang Pendidikan dan Ilmu Geografi

Volume 25, Nomor 2, Jun 2020, Hal 114-127

Sukwika, T. (2018). Kinerja pasar tenaga kerja pra dan pasca otonomi daerah dan implikasinya pada sektor pertanian di kabupaten Bogor. In R. Wibowo, A. Fauzi, L. P. Suciati, \& D. Firmansyah (Eds.), Perencanaan pembangunan wilayah dan perdesaan Indonesia: Refleksi dan gagasan ke depan (Vol. 1, pp. 239-249). Jakarta: PT Insan Sempurna Mandiri.

Sukwika, T., Yusuf, D. N., \& Suwandhi, I. (2020). The institutional of local community and stratification of land ownership in surrounding community forests in bogor. Jurnal Manajemen Hutan Tropika, 26(1), 59-71. https://doi.org/10.7226/ jtfm.26.1.59.

Sumarno, S., Hartati, S., \& Hapsari, R. C. (2015). Pemetaan status kerusakan tanah di lahan pertanian di Kecamatan Cepogo Kabupaten Boyolali. Agrosains: Jurnal Penelitian Agronomi, 17(1), 21. https://doi.org/10.20961/agsjpa.v17i1.18662.

Sushil. (2012). Interpreting the interpretive structural model. Global Journal of Flexible Systems Management, 13(2), 87-106. https://doi.org/10.1007/S40171-012-0008-3.

Syarmalina, A. A., Fatimah, E., \& Sitawati, A. (2017). Kajian kualitas lingkungan binaan di Kota Depok. In Seminar Nasional Cendikiawan ke 3 Tahun 2017 (Vol. 2, pp. 23-30). 